\title{
Captopril-induced Changes in Prostaglandin Production
}

\author{
RELATIONSHIP TO VASCULAR RESPONSES IN NORMAL MAN
}

\author{
Stephen L. Swartz, Gordon H. Williams, Norman K. Hollenberg, \\ Lawrence Levine, Robert G. Dluhy, and Thomas J. Moore, \\ Departments of Medicine and Radiology, Harvard Medical School and \\ Peter Bent Brigham Hospital, Boston, Massachusetts 02115; \\ and Department of Biochemistry, Brandeis University, \\ Waltham, Massachusetts 021.54
}

A B S T R A C T Captopril is a potent hypotensive agent whose efficacy has hitherto been attributed to its ability to alter either angiotensin II formation or kinin degradation. Our purpose was to examine captopril's acute effect on prostaglandin production, because changes in neither the renin-angiotensin nor the kallikrein-kinin systems appear adequate to account for the fall in arterial pressure. The plasma levels of angiotensin II, kinins, and prostaglandins were determined in response to increasing doses $(5$, 12.5 , and $25 \mathrm{mg}$ ) of captopril and these responses were compared with the change in arterial pressure observed in nine supine normal male subjects studied on both a high (200 meq) and low (10 meq) sodium intake.

Captopril significantly $(P<0.01)$ increased the levels of the 13,14-dihydro-15-keto metabolite of prostaglandin $\mathrm{E}_{2} \quad\left(\mathrm{PGE}_{2}-\mathrm{M}\right)$, a potent vasodilator, with similar responses being observed on both a high and a low sodium intake. No significant changes in the plasma levels of 6-keto-prostaglandin $\mathrm{F}_{1} \alpha$, or thromboxane $B_{2}$, the stable products of prostacyclin and thromboxane $A_{2}$, respectively, occurred.

The depressor response to captopril correlated with the change in $\mathrm{PGE}_{2}-\mathrm{M}(r=0.52, t=5.44, P<0.0001)$. On the other hand, although significant $(P<0.02)$ decrements in angiotensin II and increments in plasma kinins accompanied the hypotensive response in sodium-restricted subjects, in sodium-loaded subjects where the renin-angiotensin system was suppressed, no change in angiotensin II, and only a modest change in kinins was noted, even though significant $(P<0.01)$ decrements in diastolic blood pressure occurred $(-10 \pm 2 \mathrm{~mm} \mathrm{Hg})$.

Thus, changes in depressor prostaglandin production can better account for the hypotensive response to

\footnotetext{
Received for publication 7 November 1979 and in revised form 3 January 1980.
}

captopril, thereby extending to yet another vasoactive system an influence by this class of drugs and providing a new approach to dissecting the abnormality in the control of vascular tone in patients with hypertension.

\section{INTRODUCTION}

Captopril (SQ 14225, E. R. Squibb \& Sons, Inc., Princeton, N. J.), an orally active angiotensin-converting enzyme inhibitor, is a potent hypotensive agent whose mechanism of action was originally felt to be solely due to a decrease in angiotensin II formation. However, angiotensin-converting enzyme is identical to the enzyme (kininase II) that inactivates bradykinin. Therefore, converting enzyme inhibitors have the potential for not only antagonizing the generation of a powerful vasoconstrictor, but also for impairing the catabolism of a vasodilator. Recent studies have suggested that blockade of angiotensin conversion and potentiation of bradykinin generation are not linked quantitatively (1) and cannot completely account for the fall in blood pressure observed with converting enzyme inhibition (2).

Pretreatment with the prostaglandin synthetase inhibitor indomethacin, in captopril-treated animals (3), attenuated the depressor response to bradykinin, linking these systems. Moreover, indomethacin attenuated the depressor response to captopril in patients with hypertension (4). Because indomethacin is also an inhibitor of other enzyme systems (5), its lack of specificity for prostaglandin synthetase does not permit the conclusion a priori that prostaglandins are involved in mediating captopril's hypotensive response. The purpose of this study was therefore to determine if changes in prostaglandin production are important in mediating the hypotensive response to captopril. Because the activity of both the renin-angiotensin 
and plasma kallikrein-kinin systems is salt sensitive (6), dietary sodium intake could be a useful tool to assess the relative importance of the various factors potentially mediating the vascular response to captopril. In the first part of this study, captopril-treated normotensive patients were studied on a high sodium intake to suppress the activity of the renin-angiotensin and kallikrein-kinin systems and thereby isolate alterations in prostaglandin production and changes in blood pressure. Because most hypertensive patients are maintained on a restricted sodium intake and/or diuretic therapy, we also examined the relationship between the depressor and hormonal (angiotensin, kinin, and prostaglandin) responses to captopril in the sodium-restricted state, a more appropriate therapeutic model. The results of these studies, which strongly suggest that prostaglandin production is important in mediating the hypotensive response to captopril, form the basis of this report.

\section{METHODS}

Subjects. Nine normotensive male subjects, 22-33 yr of age, were studied in the Clinical Research Center of the Peter Bent Brigham Hospital, Boston, Mass. They denied use of drugs and had no evidence of renal, cardiovascular, or endocrine abnormalities on routine screening. All subjects had outpatient supine diastolic blood pressure $<90 \mathrm{~mm} \mathrm{Hg}$ determined on three different occasions. All subjects were studied supine after an overnight fast, when metabolic balance had been achieved as determined by daily 24 -h urine samples for sodium, potassium, and creatinine. Four of the subjects received an isocaloric constant dietary intake of $10 \mathrm{meq}$ sodium/100 meq potassium for $5 \mathrm{~d}$ before study, and were then placed on a $200-\mathrm{meq}$ sodium/100 meq potassium diet for an additional 5-d period prior to being restudied. Five subjects received the $200-\mathrm{meq}$ sodium/100 meq potassium diet during the first study period, and the 10-meq sodium/100 meq potassium diet during the latter study period. The protocol was approved by the Human Subjects Committee of the Peter Bent Brigham Hospital and written consent was obtained in all cases after a complete description of the protocol.

Protocol. After control blood samples for plasma renin activity (PRA), ${ }^{1}$ angiotensin II (AII), kinins, prostaglandins, sodium, and potassium were drawn through an indwelling peripheral venous catheter, converting enzyme inhibition was achieved with oral administration of captopril at 7 a.m., 1 p.m., 7 p.m., and 1 a.m. Doses of $5,12.5$, and $25 \mathrm{mg}$ were administered on successive days to five of the subjects; the remainder (four subjects) were studied on the 12.5- and $25-\mathrm{mg}$ doses. Blood samples were obtained $30,60,120 \mathrm{~min}$ and $6 \mathrm{~h}$ after administration of the drug. Blood pressures were monitored at 2-min intervals with an automatic blood pressure recorder (Arteriosonde, Roche Medical Electronics, Cranbury, N. J.) for a 30-min control period and for the initial $2 \mathrm{~h}$ of the study period; thereafter, blood pressures were monitored at 2 -h intervals with a sphygmomanometer (Tycos Laboratories, Inc., Waltham, Mass.).

'Abbreviations used in this paper: AII, angiotensin II; PGE $\mathrm{E}_{2}-\mathrm{M}$, prostaglandin $\mathrm{E}_{2}$ metabolized to 13,14-dihydro15-keto derivative; $\mathrm{PGF}_{2 \alpha}-\mathrm{M}, 6$-keto- $\mathrm{PGF}_{1 \alpha}$, the chemically stable product of prostacyclin; $\mathrm{PGI}_{2}$, prostacyclin; PRA, plasma renin activity; $\mathrm{TXA}_{2}, \mathrm{TXB}_{2}$, thromboxane $\mathrm{A}_{2}, \mathrm{~B}_{2}$.
Laboratory procedures. All blood samples were collected on ice, spun immediately, and the plasma separated and frozen until time of assay. Samples of PRA, AII, and kinins were drawn with EDTA as the anticoagulant; heparin was used as the anticoagulant in the samples for prostaglandins. In addition, polybrene was present in the samples processed for kinins. Serum and urine sodium and potassium levels were measured by flame photometry using lithium as an internal standard. PRA and AII levels were measured by radioimmunoassay techniques as previously described $(7,8)$. The lower limit of sensitivity for the AII assay is $6 \mathrm{pg} / \mathrm{ml}$. Plasma kinins were measured by a modification (9) of the radioimmunoassay techniques of Talamo and his colleagues (10).

Prostaglandin $\mathrm{E}_{2}$ is rapidly metabolized in vivo to its 13,14 dihydro-15-keto derivative. This metabolite $\left(\mathrm{PGE}_{2}-\mathrm{M}\right)$ is more stable than the primary prostaglandin and thus may more accurately reflect the cellular biosynthesis of $\mathrm{PGE}_{2}$ (11). Accordingly, the plasma concentration of $\mathrm{PGE}_{2}-\mathrm{M}$ was measured in peripheral blood by radioimmunoassay. Briefly, rabbit antiserum was raised by immunizing rabbits with $\mathrm{PGE}_{2}-\mathrm{M}$ coupled to human albumin; in the homologous anti-PGE ${ }_{2}-\mathrm{M}$ immune system, $\mathrm{PGF}_{2 \alpha}-\mathrm{M}$ cross reacts $5 \%$. All radioimmunoassays were performed on unextracted plasma. The lower limit of sensitivity of this assay was $10 \mathrm{pg} / \mathrm{ml}$, and the intraassay coefficient of variation was $<10 \%(12)$.

For radioimmunoassay of prostacyclin $\left(\mathrm{PGI}_{2}\right)$, measurement of its chemically stable product 6-keto- $\mathrm{PGF}_{1 \alpha}$ was determined by inhibition of $\left[{ }^{3} \mathrm{H}\right] 6$-keto-PGF ${ }_{1 \alpha}$ (New England Nuclear, Boston, Mass.) anti-6-keto- $\mathrm{PGF}_{1 \alpha}$ binding. In this radioimmunoassay, $\mathrm{PGE}_{2}, \mathrm{PGF}_{2 \alpha}$, thromboxane $\mathrm{B}_{2}\left(\mathrm{TXB}_{2}\right)$, and $\mathrm{PGE}_{2^{-}}$ and $\mathrm{PGF}_{2 \alpha}-\mathrm{M}$ cross react $<1 \%$. Radioimmunoassay of $\mathrm{TXB}_{2}$, the stable product of the pharmacologically active $\mathbf{T X A}_{2}$, was accomplished by inhibiting $\left[{ }^{3} \mathrm{H}\right] \mathrm{TXB}_{2}$ anti-TXB $\mathrm{TX}_{2}$ binding. In this $\mathrm{TXB}_{2}$ radioimmunoassay, $\mathrm{PGE}_{2}, \mathrm{PGF}_{2 \alpha}, 6-$ keto- $_{1 \alpha}$ and the $\mathrm{PGE}_{2}-$ and $\mathrm{PGF}_{2 \alpha}-\mathrm{M}$ cross react $<1 \%$.

Group means have been presented with the standard error of the mean as the index of dispersion. Statistical probability was evaluated with the $t$ test for parametric data (13); for nonparametric data the Wilcoxon rank-sum test (14), the Fisher exact test (15), or the chi-square test with Yates' correction (16) was used.

\section{RESULTS}

Relationship between vascular and hormonal response to converting enzyme inhibition during sodium loading. The mean urinary sodium and potassium excretion after metabolic balance was achieved on the 200-meq sodium/100 meq potassium diet were $184 \pm 12$ $\mathrm{meq} / \mathrm{d}$ and $92 \pm 8 \mathrm{meq} / \mathrm{d}$, respectively. Serum sodium (137 $\pm 1 \mathrm{meq} / \mathrm{liter})$ and potassium $(4.1 \pm 0.1 \mathrm{meq} / \mathrm{liter})$ were within normal limits for our laboratory.

The time-course responses of diastolic blood pressure, PRA, AII, and plasma kinin to $5,12.5$, and $25 \mathrm{mg}$ of captopril are shown in Fig. 1. The fall in diastolic blood pressure on the 200-meq sodium diet was dose related, with a significant decrement $(P<0.05$, chisquare test) first occurring with the 5-mg dose. The rise in PRA lagged behind the fall in blood pressure. Kinin levels changed significantly $(P<0.02$, chisquare test), but were minimal and not dose related. No significant changes in AII levels were noted (Table I).

In contrast, the changes induced by captopril in the plasma concentration of $\mathrm{PGE}_{2}-\mathrm{M}$ were highly sig- 

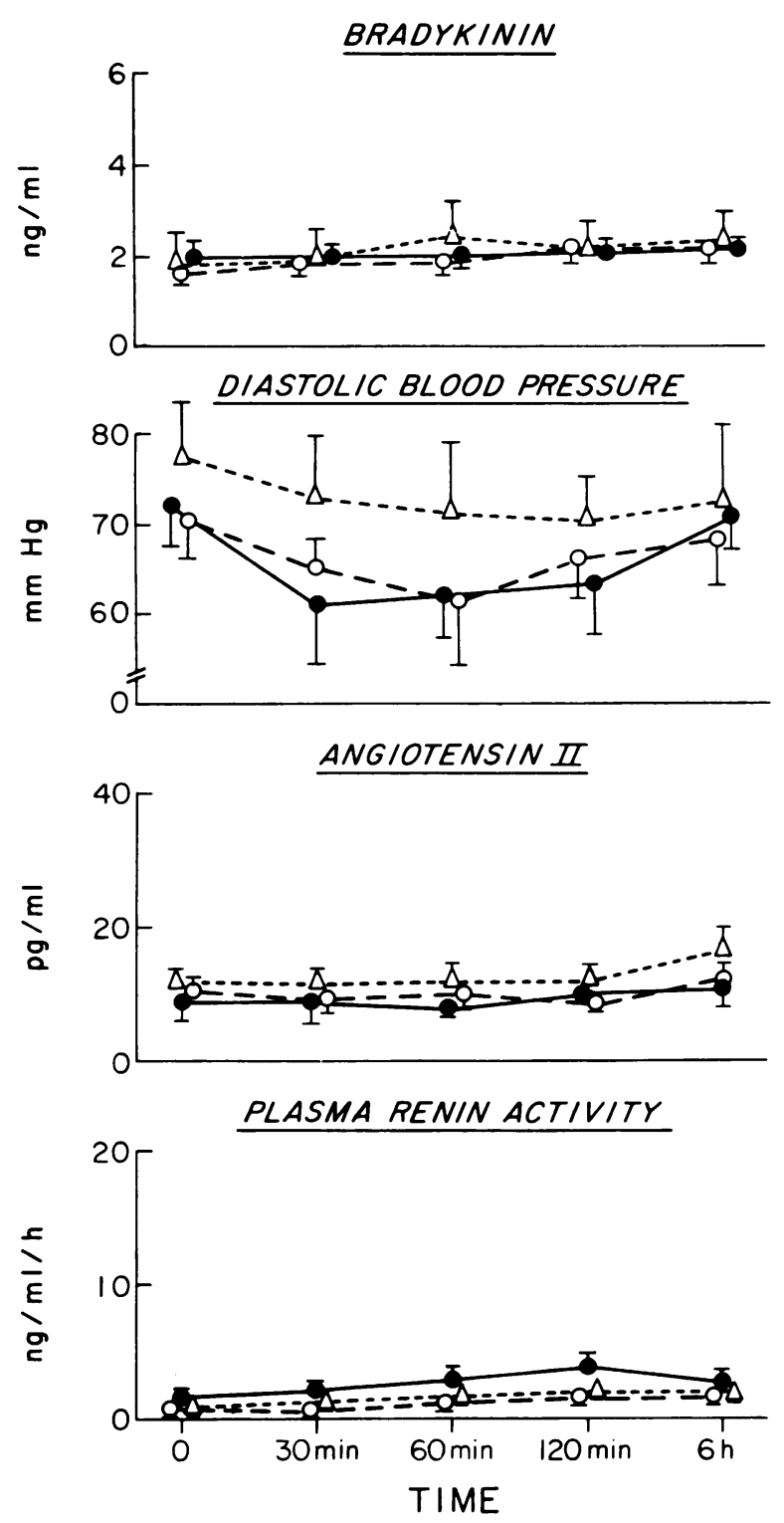

FIgURE 1 Time-course of the hormonal and vascular responses to increasing doses of captopril in subjects on a 200meq sodium/100 meq potassium intake $(n=5$ for $5(\triangle)$ and $12.5(\mathrm{O}) \mathrm{mg}$, and $6(\bigcirc)$ for $25 \mathrm{mg})($ mean $\pm \mathrm{SEM})$.

nificant $(P<0.008)$. With $25 \mathrm{mg}$, an increment of nearly threefold was produced $(P<0.01$; rank-sum test). The peak response occurred $120 \mathrm{~min}$ after administration of the drug with significant $(P<0.03$, rank-sum test) increments persisting for up to $6 \mathrm{~h}$.

Contrariwise, there were no significant changes in $\mathrm{TXB}_{2}$ levels (basal concentration of $205 \pm 34 \mathrm{pg} / \mathrm{ml}$ ). The $\mathrm{PGI}_{2}$ product 6 -keto-PGF ${ }_{1 \alpha}$ was usually at the lower level of detectability in the basal state $(10 \pm 3$ $\mathrm{pg} / \mathrm{ml}$ ) and no consistent changes were observed after administration of captopril.
Dose-response analysis of maximal vascular and hormonal changes with increasing doses of captopril (Fig. 2) revealed greater decrements in blood pressure with higher doses, with each dose significantly reducing diastolic pressure $(P<0.02)$. With larger doses, PRA continued to rise $(P<0.01)$, while AII and kinin levels were not significantly altered. In contrast, $\mathrm{PGE}_{2}-\mathrm{M}$ increased in a dose-related manner and the change in $\mathrm{PGE}_{2}-\mathrm{M}$ was significantly correlated with the change in diastolic pressure $(r=0.38, t=2.37, P<0.02)$. However, there were no significant correlations between change in diastolic pressure and AII $(r=0.02)$ or kinins
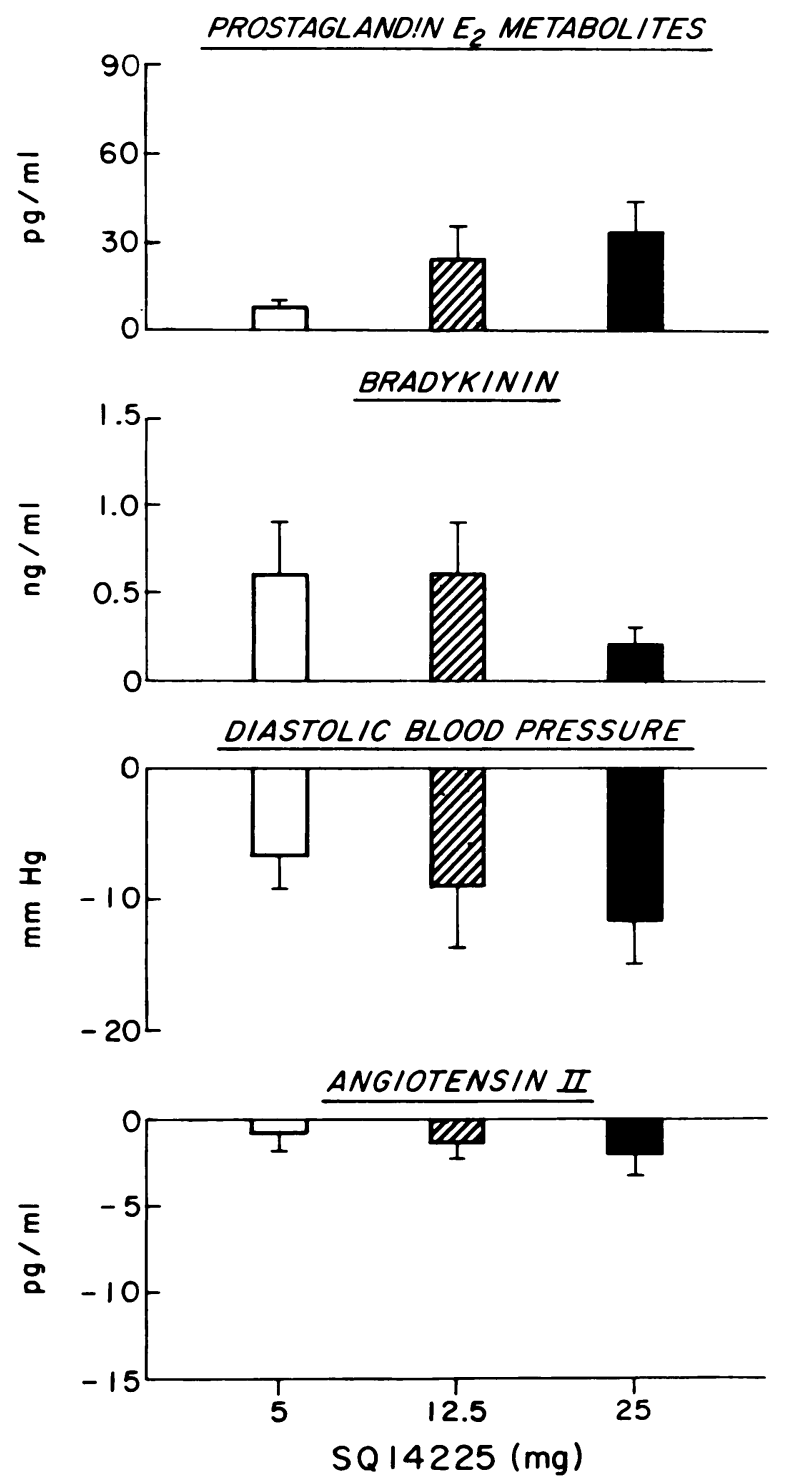

Figure 2 Maximal hormonal and vascular responses to increasing doses of captopril in subjects on a 200-meq sodium/ 100 meq potassium intake (mean \pm SEM of change from control). 
TABLE I

Vascular and Hormonal Responses to Captopril

\begin{tabular}{lcccc}
\hline \multicolumn{1}{c}{ Dose } & $\begin{array}{c}\text { Diastolic blood } \\
\text { pressure }\end{array}$ & \multicolumn{1}{c}{ PGE $_{2}-\mathrm{M}$} & AII & Kinins \\
\hline \multicolumn{1}{c}{$m g$} & & & & \\
High sodium intake & & & & \\
5 & $P<0.05$ & $0.20>P<0.25$ & $P=0.5$ & $P<0.045$ \\
12.5 & $P<0.007$ & $0.15>P<0.20$ & $P=0.5$ & $0.10>P<0.12$ \\
25 & $P<0.012$ & $P<0.03$ & $P=0.5$ & $0.16>P<0.20$ \\
All doses & $P<0.0001$ & $P<0.008$ & $P=0.5$ & $P<0.02$ \\
Low sodium intake & & & & \\
5 & $0.1>P<0.12$ & $0.09>P<0.11$ & $P=0.5$ & $0.09>P<0.11$ \\
12.5 & $P<0.0014$ & $P<0.05$ & $P<0.043$ & $P<0.018$ \\
25 & $P<0.024$ & $P<0.04$ & $P<0.022$ & $P<0.05$ \\
All doses & $P<0.0001$ & $P<0.01$ & $P<0.035$ & $P<0.01$ \\
\hline
\end{tabular}

Significance of the combined changes at 60,120 , and 360 min after administration of captopril was assessed by chi-square test.
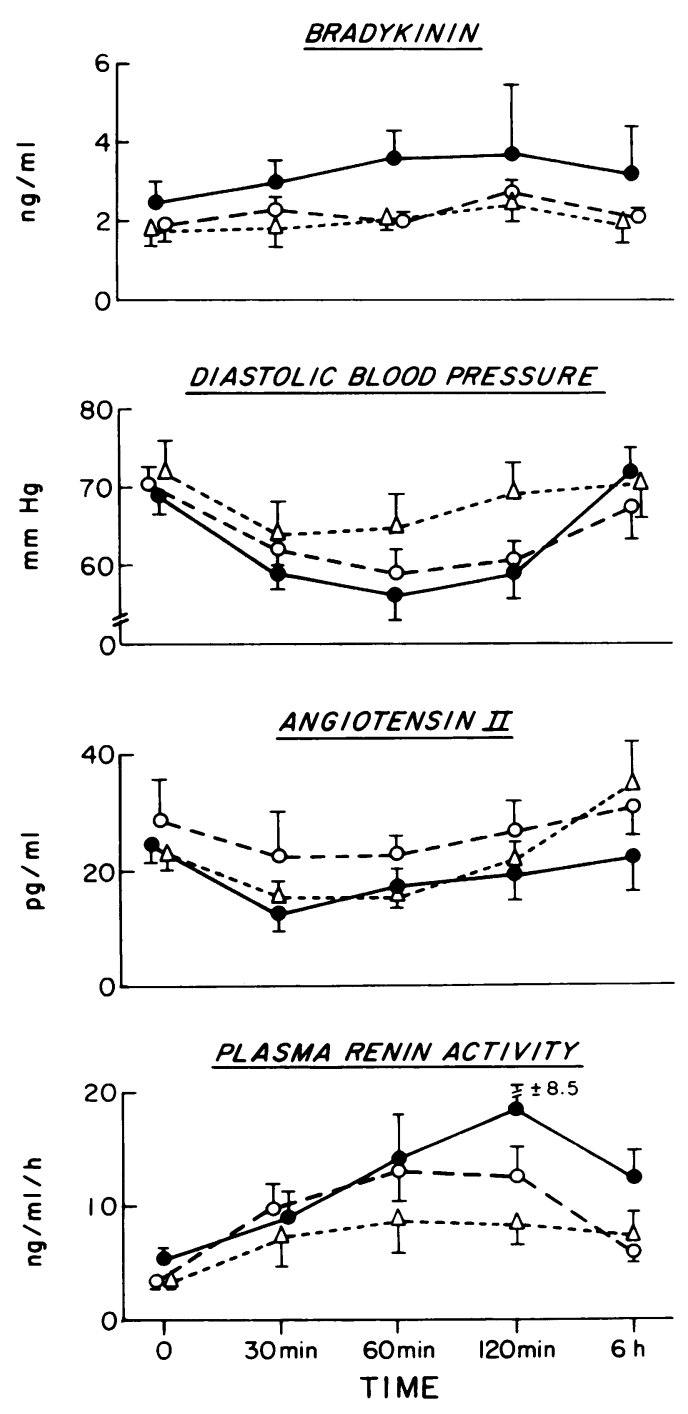

$(r=0.08)$, or between $\mathrm{PGE}_{2}-\mathrm{M}$ and either AII or kinins.

Relationship between vascular and hormonal responses to converting enzyme inhibition during sodium restriction. The mean sodium and potassium excretion after metabolic balance had been achieved on the 10 -meq sodium/100 meq potassium diet were $7 \pm 2$ and $93 \pm 6 \mathrm{meq} / \mathrm{d}$, respectively. Serum sodium $(137 \pm 1$ meq/liter) and potassium $(4.1 \pm 0.2 \mathrm{meq} / \mathrm{liter})$ were identical to that observed during sodium loading.

The time-course of diastolic blood pressure, renin activity, AII, and plasma kinin responses to $5,12.5$, and $25 \mathrm{mg}$ of captopril is shown in Fig. 3. Similar to changes noted on the 200-meq sodium diet, the fall in diastolic blood pressure was dose related, with a significant decrement $(P<0.001$, chi-square test $)$ first occurring at the 12.5-mg dose. The rise in PRA was also dose related and appeared to lag behind the fall in diastolic blood pressure. Significant decrements in AII ( $P$ $<0.043$, chi-square test), and increments in plasma kinins $(P<0.018$; chi-square test $)$ were also noted at the 12.5-mg dose (Table I).

The time-course and the magnitude of the changes in the plasma concentration of $\mathrm{PGE}_{2}-\mathrm{M}$ with captopril were similar on the high and low sodium diets. With $25 \mathrm{mg}$ of captopril the level increased more than threefold at $120 \mathrm{~min}(P<0.01)$, with a persistent elevation for as long as $6 \mathrm{~h}(P<0.03)$ (Fig. 4). Smaller increments were observed with the 5- and 12.5-mg doses of captopril. As on the high sodium diet there were no consistent changes in the plasma concentration of $\mathrm{PGI}_{2}$ or $\mathrm{TXB}_{2}$.

FIGURE 3 Time-course of the response of hormonal factors and blood pressure to three doses of captopril in subjects on a 10 -meq sodium $/ 100 \mathrm{meq}$ potassium diet $(n=5$ for $5(\triangle) \mathrm{mg}$, 8 (O) for $12.5 \mathrm{mg}$ and 7 for $25(\bigcirc) \mathrm{mg}$ ) (mean \pm SEM). 


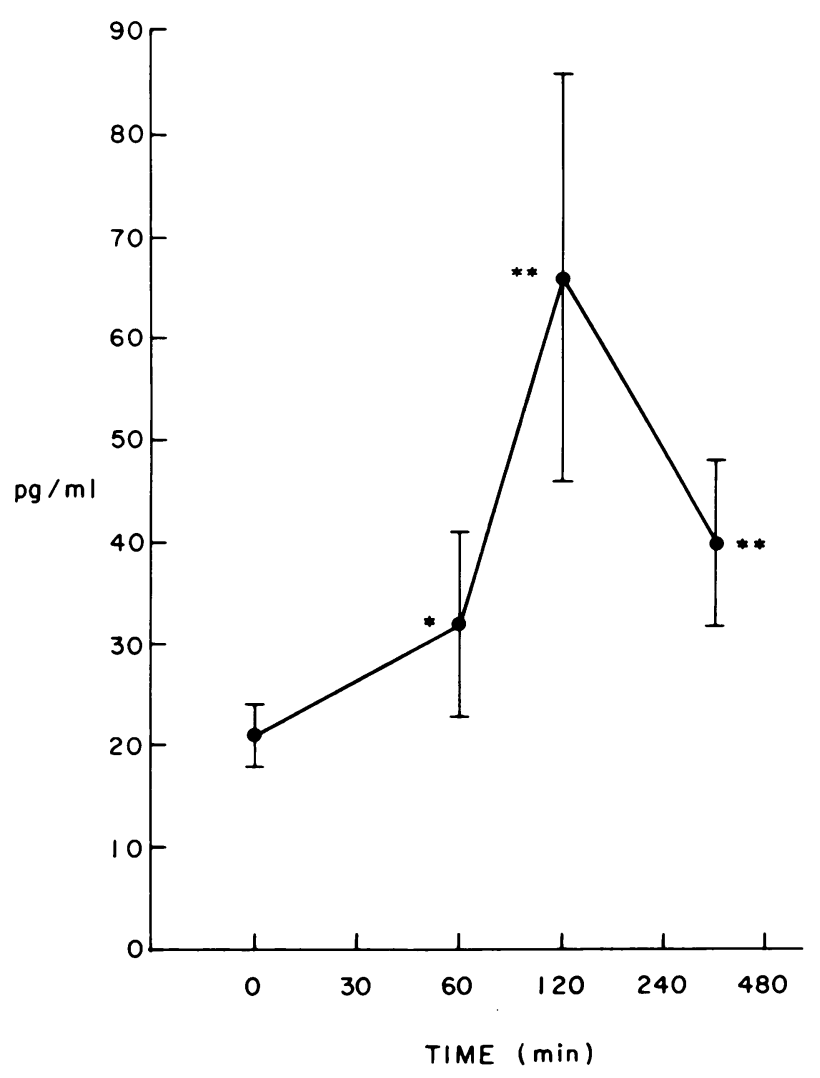

Figure 4 Time-course of the changes in plasma $\mathrm{PGE}_{2}-\mathrm{M}$ concentration in response to $25 \mathrm{mg}$ of captopril. The values represent the mean \pm SEM of levels measured in subjects on a high or a low sodium diet (total studies $=13)(* * P<0.02$, $* P<0.05)$.

A dose-response analysis of maximal changes in diastolic blood pressure, PRA, AII, and plasma kinins with increasing doses of captopril (Fig. 5) demonstrated that there was no significant difference in the decrement in diastolic blood pressure between the 12.5- and 25-mg dose. Nevertheless, PRA continued to rise and plasma AII continued to fall with increasing doses. Also, no further changes in plasma kinins were noted. There were highly significant correlations between the changes in $\mathrm{PGE}_{2}-\mathrm{M}$ and diastolic pressure $(r=0.58, t=4.78, P<0.0001)$ and between the changes in AII and diastolic pressure $(r=0.54, t$ $=4.54, P<0.0001)$. In contrast, there were no significant correlations between kinin changes and blood pressure $(r=0.25 ; t=1.79)$ or between $\mathrm{PGE}_{2}-\mathrm{M}$ changes and either AII $(r=0.11)$ or kinin $(t=0.13)$ changes. With the use of multiple linear regression techniques, the addition of the AII data to the $\mathrm{PGE}_{2}-\mathrm{M}$ data moderately improved the correlation with blood pressure $(r=0.72, t=5.8, P<0.0001)$. There was no further improvement when the kinin data was also added.

\section{DISCUSSION}

Blockade of angiotensin-converting enzyme by oral administration of captopril lowered diastolic blood pressure in all nine normotensive subjects. Similar to previous clinical experience with converting enzyme inhibitors, our study demonstrated that sodium restriction enhanced blood pressure reduction $(17,18)$, and that increasing the dose of captopril beyond $12.5 \mathrm{mg}$ did not significantly amplify the antihypertensive effect, but rather prolonged its duration (19).

The mechanism by which blood pressure is lowered still remains unclear. The possibilities include $(a)$ a direct vasodilatory effect; $(b)$ a direct central nervous system effect; $(c)$ interference with the pressor effect of AII by blockade of its formation; (d) impairment of
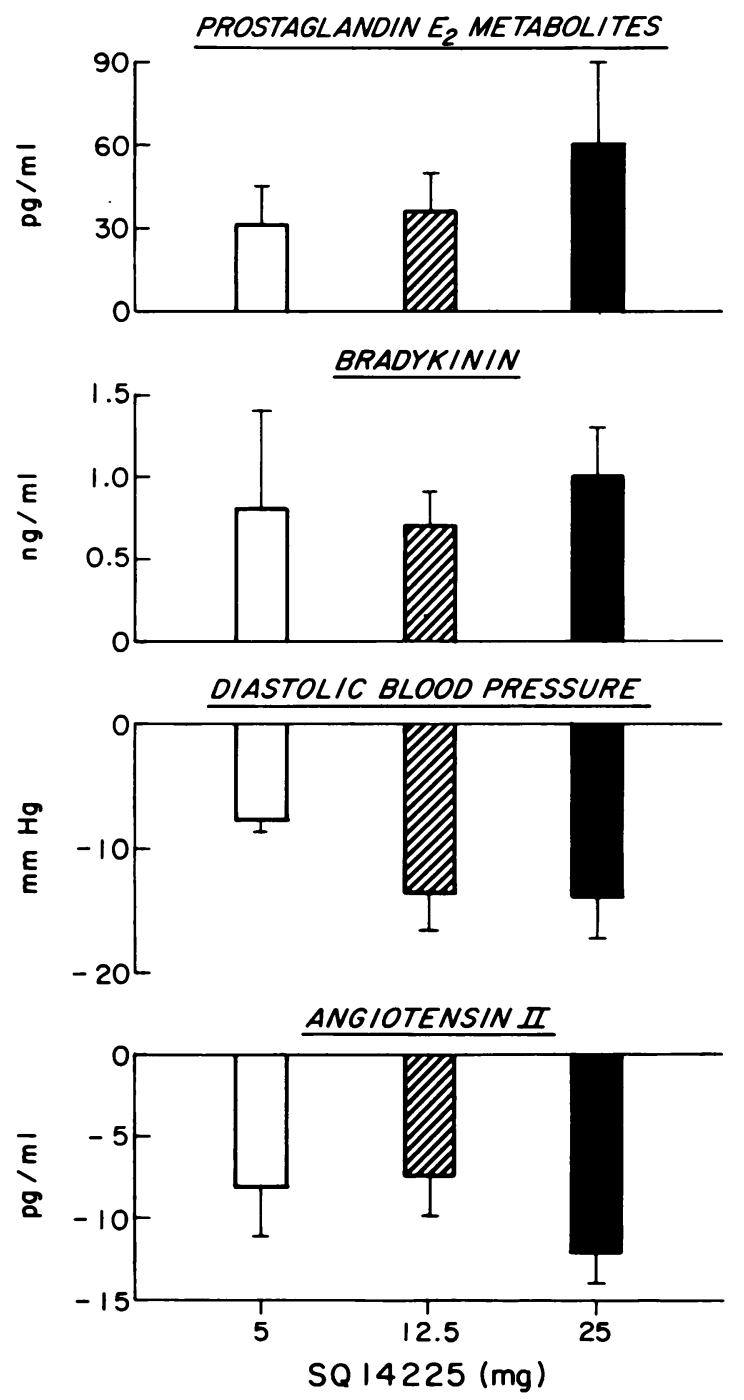

Figure 5 Maximum hormonal and vascular responses to increasing doses of captopril in subjects on a 10-meq sodium/ 100 meq potassium diet (mean $\pm \mathrm{SEM}$ of change from control). 
the degradation of vasodilatory plasma kinins; and/or $(e)$ increased production of vasodepressor prostaglandins. Studies have demonstrated that captopril has no direct vasodilatory effect $(20)$ and that it does not cross the blood-brain barrier (21). The most convincing evidence to date that inhibition of AII generation cannot alone account for the antihypertensive effect of converting enzyme inhibitors, was the demonstration that the plasma AII level required to restore postconverting enzyme inhibitor blood pressure to control was significantly higher than control plasma AII levels (2). The present study further documents the observation that factors in addition to interruption of AII generation are responsible for the hypotensive response. On the 200-meq sodium diet, a significant hypotensive response occurred despite the fact that no change in plasma AII was noted. This failure to observe a change in AII concentration could not be explained by methodologic factors because low basal AII levels $(10-11) \mathrm{pg} / \mathrm{ml})$ were still greater than the sensitivity of the assay $(6 \mathrm{pg} / \mathrm{ml})$.

Likewise, changes in plasma kinins alone cannot adequately explain the hypotensive effect. Although significant changes in kinin levels were recorded on both high and low sodium intake, the increments were small, not dose related, and did not correlate with changes in blood pressure. Although changes in plasma AII and kinins cannot fully account for the sustained depressor response to converting enzyme inhibition, this should not be interpreted as implying that blockade of AII formation and reduction of plasma kinin degradation are not important factors contributing to the hypotensive response.

The search for other mediators of the vascular response to captopril has recently focused on the prostaglandins. These lipid compounds have induced a fall in blood pressure and an increase in renal blood flow and urinary sodium excretion when infused intravenously into hypertensive humans (22). Moreover, prostaglandin release has been shown to be stimulated by AII and bradykinin (23). Angiotensin-induced renal vasoconstriction is associated with release of prostaglandins (24) and this renal vasoconstriction is enhanced when prostaglandin biosynthesis is inhibited by indomethacin (25). In addition, blood vessels release $\mathrm{PGE}_{2}$, a potent vasodilator, when treated with AII or bradykinin in vitro (26). Teprotide (SQ 20881, E. R. Squibb \& Sons, Inc.), the nonapeptide-converting enzyme inhibitor, decreased $\mathrm{PGE}_{2}$ release by angiotensin I, enhanced the release by bradykinin, and did not affect release by AII in vitro (23).

In vivo the same agent increased prostaglandin in patients with essential hypertension who were ingesting a moderate sodium intake, but not when ingesting a low sodium intake (27). Unfortunately, even on the higher sodium intake teprotide reduced plasma AII concen- tration, making it impossible to ascertain the relative influence of changes in AII and prostaglandins in the depressor response. Furthermore, no normal subjects were studied.

Accordingly, we performed our study on sufficiently different sodium intakes to guarantee a prominent contribution of AII on the one hand and virtually complete suppression of it on the other. Furthermore, we assessed changes in $\mathrm{PGE}_{2}-\mathrm{M}$, in $\mathrm{TXB}_{2}$, and in the $\mathrm{PGI}_{2}$ transformation product 6-keto- $\mathrm{PGF}_{1 \alpha}$ in response to converting enzyme inhibition, since the primary prostaglandins are labile. Although no significant or consistent changes in 6-keto-PGF ${ }_{1 \alpha}$ or $\mathrm{TXB}_{2}$ were noted, significant increments in $\mathrm{PGE}_{2}-\mathrm{M}$ occurred in a dose-related pattern on both a high and low sodium intake. Endogenous $\mathrm{PGE}_{2}$ has been demonstrated to increase renal blood flow by acting as a physiological antagonist to renal vasoconstrictor substances (28). $\mathrm{PGI}_{2}$ are also vasodilators, being four to eight times more potent than $\mathrm{PGE}_{2}$ in this regard (29), and are the major product of prostaglandin synthesis in vascular tissue in man (30). Our inability to detect significant increments in the stable transformation product of $\mathbf{P G I}_{2}$ (6-keto-PGF $\left.{ }_{1 \alpha}\right)$ may have been due to $(a)$ changes in the concentration of 6-keto-PGF ${ }_{1 \alpha}$ below the sensitivity of our assay, or $(b)$ faulty estimation of $\mathrm{PGI}_{2}$ generation by measuring 6-keto- $\mathrm{PGF}_{1 \alpha}$ rather than 6,15-diketo- $P G F_{1 \alpha}$ (31). Recent studies have demonstrated that a 15hydroxyprostaglandin dehydrogenase of high activity is present in vascular tissue and can metabolize in vivo $\mathrm{PGI}_{2}$ or 6 -keto-PGF ${ }_{1 \alpha}$ to 6,15 -diketo-PGF $1 \alpha(31)$. Thus, activation of prostaglandin synthesis, either secondary to increased kinin levels or as a direct effect of captopril on phospholipase activity, could result in increased formation of $\mathrm{PGE}_{2}$ and $\mathrm{PGI}_{2}$, which could in turn contribute to the hypotensive response. The former was documented in this study, the latter was not.

The results of the single and multiple linear regression techniques provide some insight into the relationship between the changes in arterial pressure and the hormonal changes with captopril. Changes in blood pressure correlated best with changes in $\mathrm{PGE}_{2}-\mathrm{M}$. On the high sodium diet the changes in arterial pressure correlated only with changes in $\mathrm{PGE}_{2}-\mathrm{M}$, whereas on the low sodium diet, changes in AII and to a lesser extent kinin levels, probably also contributed to captopril's hypotensive effect.

How accurately the measured plasma levels of these hormones reflect events going on in the vascular tissue is uncertain. Measurements of all three classes of hormones are difficult because potentially the collection process itself may increase the formation or degradation of the specific hormone. Furthermore, all assays, except that for kinins, were performed on unprocessed plasma with the possibility that cross-reacting material 
may either mask or contribute to the actual levels. With the prostaglandin measurements an additional variable needs to be considered since a metabolite rather than the active hormone was determined. As noted earlier, this could possibly account for our failure to detect a change in $\mathrm{PGI}_{2}$ production. Yet, data are available which suggest that there is a relationship between the plasma levels and the vascular responses for each of these hormones. When bradykinin is infused into the dog there are parallel changes in blood pressure and plasma kinin levels with a reduction in diastolic pressure of $10 \mathrm{~mm} \mathrm{Hg}$ being related to an increment in plasma kinins of $1 \mathrm{ng} / \mathrm{ml}$ (32). Likewise, an AII infusion producing a $5-10-\mathrm{mm} \mathrm{Hg}$ rise in mean pressure is accompanied by a $5-15-\mathrm{pg} / \mathrm{ml}$ increase in plasma AII levels (33). Finally, observations from our laboratory (4) also indicate that alterations in prostaglandin production participate in the hypotensive effect of captopril, since pretreatment with indomethacin, a prostaglandin synthesis inhibitor, significantly diminishes the depressor response to captopril.

In conclusion, the vascular response to captopril is complex and varies with the degree of sodium intake. Captopril induced a fall in arterial pressure on both the high and low sodium diets, but the mechanisms responsible for this effect may not be the same. In sodium-loaded patients, the fall in blood pressure was accompanied primarily by changes in plasma $\mathrm{PGE}_{2}-\mathrm{M}$. Although a similar increase in $\mathrm{PGE}_{2}-\mathrm{M}$ was seen in the sodium-restricted subjects, the hypotensive response was enhanced, most probably because significant changes in plasma levels of AII and to a smaller extent, kinins also occurred. Thus, this study suggests that prostaglandins play an important role in mediating the hypotensive response to captopril over the wide range of sodium ingested by human subjects. Whether captopril's effect on prostaglandin production is direct or secondary to a change induced in another system is unclear from the present study.

\section{ACKNOWLEDGMENTS}

It is a pleasure to acknowledge the assistance provided in various portions of this study by Ms. Rita O'Donnell, Christine Barry, Betty Mahoney, and Rodical Emanuel. The SQ 14225 was supplied by Dr. R. Vukovich and Dr. D. McKinstry of the E. R. Squibb \& Sons, Inc., Princeton, N. J.

This work was supported by grants from the National Institutes of Health (HL 14944, GM 18632, HL 16821, HL 18882, HL 05832, AM 01629, HL 05144) and a contract from the National Airspace Agency (NSG 9078). The studies were performed at a Clinical Research Center supported by a grant from the Division of Research Resources of the National Institutes of Health (5-M01-RR00888).

\section{REFERENCES}

1. Ondetti, M. A., B. Rubin, and D. W. Cushman. 1977. Design of specific inhibitors of angiotensin-converting enzyme: new class of orally active antihypertensive agents. Science (Wash. D. C.). 196: 441-444.

2. Swartz, S. L., G. H. Williams, N. K. Hollenberg, T. J. Moore, and R. G. Dluhy. 1979. Converting enzyme inhibition in essential hypertension: the hypotensive response does not reflect only reduced angiotensin II formation. Hypertension. 1: 106-111.

3. Murthy, V. S., T. L. Waldron, and M. E. Goldberg. 1978. The mechanism of bradykinin potentiation after inhibition of angiotensin-converting enzyme by SQ 14,225 in conscious rabbits. Circ. Res. 43(Suppl. I): I-40-45.

4. Crantz, F. R., S. L. Swartz, N. K. Hollenberg, T. J. Moore, R. G. Dluhy, L. Levine, and G. H. Williams. 1979. Role of prostaglandins in the hypotensive response to captopril in essential hypertension. Clin. Res. 27: 592A. (Abstr.)

5. Ohuchi, K., and L. Levine. 1978. Tumor promoting phorbol diesters stimulate release of radioactivity from $\left[{ }^{3} \mathrm{H}\right]$-arachidonic acid labeled-but not $\left[{ }^{14} \mathrm{C}\right]$ linoleic acid labeled-cells. Indomethacin inhibits the stimulated release from $\left[{ }^{3} \mathrm{H}\right]$ arachidonate labeled cells. Prostaglandins Med. 1: 421-431.

6. Wong, P. Y., R. C. Talamo, G. H. Williams, and R. W. Coleman. 1975. Response of the kallikrein-kinin and renin-angiotensin systems to saline infusion and upright posture. J. Clin. Invest. 55: 691-698.

7. Underwood, R. H., and G. H. Williams. 1972. The simultaneous measurement of aldosterone, cortisol, and corticosterone in human peripheral plasma by displacement analysis. J. Lab. Clin. Med. 79: 848-862.

8. Emanuel, R., J. P. Cain, and G. H. Williams. 1973. Double antibody radioimmunoassay of renin activity and angiotensin II in human peripheral plasma. J. Lab. Clin. Med. 81: $632-640$.

9. Williams, G. H., and N. K. Hollenberg. 1977. Accentuated vascular and endocrine response to SQ 20881 in hypertension. N. Engl. J. Med. 297: 184-188.

10. Talamo, R. C., E. Haber, and K. F. Austen. 1969. A radioimmunoassay for bradykinin in plasma and synovial fluid. J. Lab. Clin. Med. 74: 816-827.

11. Beguin, F., M. Bygdeman, K. Green, B. Samuelson, M. Toppozada, and N. Wiquist. 1972. Analysis of prostaglandin $\mathrm{F}_{2}$ and metabolites in blood during constant infusion of prostaglandin $F_{2}$ in the human female. Acta Physiol. Scand. 86: 430-432.

12. Lackritz, R., D. Tulchinsky, K. J. Ryan, and L. Levine. 1978. Plasma prostaglandin metabolites in human labor. Am. J. Obstet. Gynecol. 131: 484-489.

13. Snedecor, G. W., and W. G. Cochran. 1967. Statistical Methods. Iowa State University Press, Ames, Iowa. 6th edition. 59-60.

14. Fisher, R. A. 1958. Statistical Methods. Hafner Publishing Company, New York. 13th edition. 96-97.

15. Ipsen, J., and P. Feigl. 1970. Bancroft's Introduction to Biostatistics. Harper and Row, Publishers, Inc., New York. 1st edition. 81-84.

16. Armitage, P. 1971. Statistical Methods in Medical Research. Blackwell Scientific Publications, Ltd., Oxford. lst edition. 131-135.

17. Bravo, E. L., and R. C. Tarazi. 1979. Converting enzyme inhibition with an orally active compound in hypertensive man. Hyertension. 1: 39-46.

18. Cody, R. J., Jr., R. C. Tarazi, E. L. Bravo, and F. M. Fouad. 1978. Haemodynamics of orally-active converting enzyme inhibition (SQ 14225) in hypertensive patients. Clin. Sci. Mol. Med. 55: 453-459.

19. Brunner, H. R., H. Gavras, B. Waeber, G. R. Kershaw, G. W. Turini, R. A. Vukovich, D. N. McKinstry, and I. Gavras. 1979. Oral angiotensin-converting enzyme in- 
bitor in long-term treatment of hypertensive patients. Ann. Intern. Med. 90: 19-23.

20. Murthy, V. S., T. L. Waldron, M. E. Goldberg, and R. R. Vollmer. 1977. Inhibition of angiotensin converting enzyme by SQ 14225 in conscious rabbits. Eur.J. Pharmacol. 46: $207-212$.

21. Vollmer, R. R., and J. A. Boccagno. 1977. Central cardiovascular effects of SQ 14,225, an angiotensin-converting enzyme inhibitor in chloralose-anesthetized cats. Eur. J. Pharmacol. 45: 117-125.

22. Hornych, A., M. Safar, N. Papanicolaou, P. Meyer, and P. Milliez. 1972. Renal and cardiovascular effects of prostaglandin $\mathrm{A}_{2}$ in essential hypertension. Eur. J. Clin. Invest. 2: 289A. (Abstr.)

23. Blumberg, A. L., S. E. Denny, G. R. Marshall, and P. Needleman. 1977. Blood vessel-hormone interactions: angiotensin, bradykinin, and prostaglandins. Am. J. Physiol. 232 (3): H305-H310.

24. Needleman, P., A. H. Kauffman, J. R. Douglas, E. M. Johnson, Jr., and G. R. Marshall. 1973. Specific stimulation and inhibition of renal prostaglandin release by angiotensin analogs. Am. J. Physiol. 224: 1415-1419.

25. Aiken, J. W., and J. R. Vane. 1976. Intrarenal prostaglandin release attenuates the renal vasoconstrictor activity to angiotensin. J. Pharmacol. Exp. Ther. 184: 678-687.

26. Tuvemo, T., and L. Wide. 1973. Prostaglandin release from the human umbilical artery in vitro. Prostaglandins. 4: 689-694.
27. Vinci, J. M., D. Horwitz, R. M. Zusman, J. J. Pisano, K. J. Catt, and H. R. Keiser. 1979. The effect of converting enzyme inhibitor with SQ 20881 on plasma and urinary kinins, prostaglandin E, and angiotensin II in hypertensive man. Hypertension. 1: 416-426.

28. Vander, A. J. 1968. Direct effects of prostaglandin on renal function and renin release in anaesthetized dog. Am.J. Physiol. 214: 218-222.

29. Armstrong, J. M., N. Lattimer, S. Moncado, and J. R. Vane. 1978. Comparison of the vasodepressor effects of prostacyclin and 6-oxo-prostaglandin $\mathrm{F}_{1 \alpha}$ with those of prostaglandin $\mathrm{E}_{2}$ in rats and rabbits. Br. J. Pharmacol. 62: $125-130$.

30. Moncada, S., and J. R. Vane. 1979. Arachidonic acid metabolites and the interactions between platelets and blood vessel walls. N. Engl. J. Med. 300: 1142-1147.

31. Wong, P. Y. K., F. F. Sun, and J. C. McGiff. 1978. Metabolism of prostacyclin in blood vessels. J. Biol. Chem. 253: 5555-5557.

32. Katz, J., G. H. Williams, and N. K. Hollenberg. Relationship between vascular responses and plasma kinin levels to infused bradykinin in the dog. Clin. Res. In press.

33. Hollenberg, N. K., W. R. Chenitz, D. F. Adams, and G. H. Williams. 1974. Reciprocal influence of salt intake on adrenal glomerulosa and renal vascular responses to angiotensin II in normal man. J. Clin. Invest. 54: 34-42. 